\title{
Conflicts of Criminal Jurisdiction of States and Extradition Issues
}

\author{
${ }^{1}$ Alfiya R. Kaumova, ${ }^{2}$ Rimma I. Efremova \\ ${ }^{1,2}$ Russian Federation, Kazan Federal University, Law Faculty \\ Email: alfiya_kaumova@inbox.ru,riimma.shakirova@gmail.com
}

Received: 02 ${ }^{\text {nd }}$ November 2018, Accepted: $2^{\text {th }}$ November 2018, Published: $31^{\text {st }}$ December 2018

\begin{abstract}
The paper analyzes the issues of state jurisdictional competition, and also extradition issues. The authors consider in detail issues related to the conflict between jurisdictions, namely collisions between criminal jurisdictions, and the issues of extradition as a means of resolving collisions between criminal jurisdictions of states.
\end{abstract}

\section{Keywords}

Criminal Jurisdiction; Jurisdiction of States; Extradition; Aut Dedere Aut Judicare; Competition between Jurisdictions, International Criminal Law

\section{Introduction}

The existence in international law of different legal bases for the exercise of criminal jurisdiction (principles of territoriality, active and passive nationality, protection and universal) necessarily implies a conflict or competition between the jurisdictions of States. O. S. Chernichenko determines competition of the jurisdiction of the States as "establishing at the same time the jurisdiction of the various States in relation to one and the same person (or persons) or objects, as well as the exercise or attempted exercise of its jurisdiction in relation to relevant person (s) or objects". It also notes that competition of jurisdiction should be considered if each state concerned, when establishing or claiming to exercise its jurisdiction, does not go beyond the limits provided by international law, based on a particular jurisdictional principle (criteria).

\section{Methods}

In international legal doctrine, there are two categories of conflict of jurisdiction - positive (when several States claim jurisdiction) and negative (when no state claims it). Since in practice situations where no state is able to exercise jurisdiction are difficult to imagine, the conflict of jurisdiction is always viewed in a positive light. In this case, conflicts may occur when:

a) several States claim jurisdiction over the offence on the basis of the place of Commission of the offence or the presence of the accused, or on the basis of the principles of active or passive nationality, protection of their own security and universal (conflict of territorial and extraterritorial jurisdiction);

b) several States claim jurisdiction over the offence on account of the place of Commission (conflict of territorial jurisdiction);

c) several States claim jurisdiction over offences committed in foreign territory, citing principles such as active and passive nationality, protection and universal (conflict of extraterritorial jurisdiction) as the basis.

In General, the existence of competition jurisdiction is not contrary to international law. The resolution of a conflict of jurisdiction requires some form of agreement between the States concerned on the measures to be taken, so conflicts of jurisdiction that may arise between the States concerned as a result of the simultaneous operation of several legal bases for the exercise of jurisdiction are usually resolved by bilateral or multilateral treaties. If we consider the conflict of criminal jurisdictions, these are numerous specialized conventions on combating a particular crime, bilateral and regional agreements on legal assistance in criminal cases, transfer of proceedings and extradition of criminals.

For many years, the decision in Lotus (France V. Turkey) in the proceedings of the Permanent court of international justice in 1927 remained almost the only legal source for resolving conflicts of jurisdiction and filling gaps in this matter. In 1965 within the framework of the Council of Europe attempted to resolve the issue in terms of competition criminal jurisdictions as a whole through the development of a special European Convention on conflicts of jurisdiction in criminal matters (Draft European Convention on Conflicts of Jurisdiction in Criminal Matters). The draft Convention was not proposed for adoption, although much of its provisions formed the basis of the 1972 European Convention on the transfer of criminal proceedings.

At the informal level, the Princeton University draft principles of universal jurisdiction (principle 8) formulated a proposal to resolve conflict of jurisdiction situations. - Resolving conflicts of national jurisdictions): "When more than one state claims or could claim that he had jurisdiction in respect of any person and when the state, in possession of that person, there is no basis for jurisdiction but the principle of universality, that state or its judicial authorities, when deciding on whether or not to exercise the prosecution or extradition, basing its decision on the basis of the analysis of the following criteria:

- multilateral or bilateral Treaty obligations;

- crime scene;

- nationality of the alleged perpetrator and his relationship with the requesting state; 
- nationality of the victim and his / her relationship with the requesting state;

- any other connection between the requesting state and the alleged perpetrator, crime or victim;

- likelihood, integrity and effectiveness of prosecution in the requesting state;

- fairness and impartiality of proceedings in the requesting state;

- convenience for the parties and witnesses, as well as the availability of evidence in the requesting state; and

- interests of justice.

In 2009, under the auspices of The International Association of prosecutors, guidelines for the settlement of conflicts of jurisdiction were developed on the basis of Treaty and case law, containing criteria (primary and secondary) for determining the advantages of the state's criminal jurisdiction in the event of competition.

First of all, the state competent authorities are recommended to answer the following questions as soon as possible: under whose jurisdiction the crime occurred; where it is most realistic to investigate; whether there is potential competition of jurisdiction (the presence of legal grounds); what are the international Treaty obligations (whether there is an alternative to aut dedere aut judicare).

The determination of the priority of a jurisdiction at the Treaty level greatly helped to cope with the problems posed by competition, but not entirely, since the framework was generally not sufficiently clear. Such treaties do not create a General regime, which is in principle understandable given the very different legal mechanisms for the exercise of administrative, civil and criminal jurisdiction. In addition, it is necessary to distinguish between the competition of substantive (prescriptive, legislative, legal) jurisdiction and procedural (Executive and judicial): the first, though relevant, but still is only potential, while the second from the point of view of its practical implementation raises a large number of questions.

Conflict of territorial and extraterritorial criminal jurisdiction. As noted earlier, jurisdictional activity within its own national borders is a manifestation of the sovereignty of the state. In the Lotus case, the Permanent court of international justice noted that "the first and foremost limitation imposed by international law on a state is that, in the absence of a permissive rule, a state cannot exercise its power in any form within the territory of another state". This postulate has become firmly established in contemporary international law. As noted by Martin Dixon, one of the principles derived from this process is the full and absolute jurisdiction of the state within its own territory: "...no other power... may not exercise coercive jurisdiction on state territory, and issues arising under domestic jurisdiction, can not serve as the subject of international claims, except in special cases (such as human rights) [1].

It is therefore perfectly justified to establish at the international Treaty level the primacy of territorial jurisdiction over all crimes committed in state territory.

A typical example is the provisions of the United Nations Convention against transnational organized crime of 2000 , which provides that States parties shall carry out their obligations in accordance with the principles of sovereign equality, territorial integrity and non-interference in the internal Affairs of States (art.4, para. 1). According to article 15, paragraph 1 , of the Convention, "a state party shall take such measures as may be necessary to establish its jurisdiction over crimes..

(a) The offence is committed in the territory of the state party; or

(b) The offence is committed on Board a vessel which carried the flag of that state party at the time of the Commission of the offence or an aircraft which is registered under the law of that state party at that time."

The unconditional priority of territorial and quasi-territorial jurisdiction established in the Convention makes the possibility of extraterritorial jurisdiction secondary (art.15, para. 2), and deprives the state party of the right "to exercise in the territory of another state jurisdiction and functions that are exclusively within the competence of the bodies of that other state in accordance with its domestic legislation" (art. 4p.2).

Such provisions on the resolution of conflict-of-law issues of criminal jurisdiction are found in the vast majority of treaties dealing with individual transnational crimes.

However, as noted by O. S. Chernichenko, "the mention in these treaties, first of all, of territorial (or quasi-territorial) jurisdiction ... can only speak about which of them should be considered in the first place, i.e. about the actual advantage, and not about the priorities in the literal sense" and "...nothing prevents States from proving the greater validity of their claims to establish and exercise their jurisdiction" [2].

It seems that the principle of sovereign equality of States, assuming the full supremacy of the state on its territory, leaves no choice in the case of competition of territorial and extraterritorial jurisdiction, asserting the right of the territory. This is particularly clear in the case of state criminal jurisdiction. N. Ah.Safarov argues that " despite the absence of a specific Treaty instrument to regulate the competition of different criminal jurisdictions, there is General acceptance in international criminal law of the approach that, in cases of competing jurisdiction, the issue of extradition should fall within the competence of the receiving state of the person whose extradition is required in connection with the Commission of the crime, and that it should decide on the matter. This position is in full compliance with the concept of state sovereignty and its most important component — territorial supremacy" [3].

\section{Results and Discussion}

Conflicts of territorial criminal jurisdiction. A conflict of territorial jurisdiction arises when several States claim jurisdiction over an offence because of the place of Commission. In its recommendation to the Committee of Ministers of the Council of Europe, the Consultative Assembly attempted to define a scale of priorities in this sense. The starting point of this recommendation was that the state where the offence was committed, that is, the place where the offence 
was committed, should have the advantage of prosecuting the offender. Other criteria should be derived from this principle.

What is considered in this case the place of Commission of the crime-it is obvious that the actual state territory, that is, the one that is under the sovereignty of any state. In addition, the jurisprudence of individual countries assumes that the definition of "state" includes the territory that is under its effective management. Namely, some objects located outside the state territory, the status of which is determined by international treaties. These objects continue to maintain a legal relationship with the state, even outside its state borders, so they are perceived in some cases as state territory (the term "conditional territory" or "quasi-territory" is sometimes applied to such objects in international legal doctrine). These are air, sea and river vessels; spacecraft, stations and other space objects; artificial Islands and structures at sea and on its bottom; scientific stations in Antarctica; premises of diplomatic and consular missions. Article 11 of the criminal code, defining the limits of territorial jurisdiction of Russia, States that a person shall be liable under this Code if he has committed a crime: 1) on the territory of the Russian Federation; 2) within the territorial sea or airspace of the Russian Federation; 3) on the continental shelf and in the exclusive economic zone of the Russian Federation; 4) on a vessel assigned to the port of the Russian Federation, located in open water or air space outside the Russian Federation; 5) on a military ship or military aircraft of the Russian Federation, regardless of their location.

The problem of the crime scene continues to generate debate in the criminal law doctrine of States. The fact is that the principle of territoriality, which is the basis of territorial jurisdiction, has recently been expanded in theory and practice in connection with the variety of situations covered by it.

In this regard, with regard to the Russian criminal law, it is proposed to interpret the term "Commission of a crime" taking into account the moment of its beginning and end, namely, to amend part 1 of article 11 of the criminal code of the Russian Federation, and to recognize the crime committed on the territory of the Russian Federation, which "was started, continued or ended on its territory, or committed in complicity with persons who carried out criminal activity on the territory of a foreign state" [4]

Conflicts of extraterritorial jurisdiction of States are evident if the crime is committed outside the territory of a state, but for some legal reason it falls under the jurisdiction of that state (conflict of extraterritorial jurisdiction).

In the Lotus case, the international justice Chamber noted that there was no rule of international law that prohibited a state from exercising jurisdiction over an alien for a crime committed outside its territory. The main motives influencing the attempts of countries to extend their jurisdiction in the case of a crime committed abroad are: the existence of a legal link between the offender or the victim of the crime and that state (active or passive citizenship); ensuring one's own security (the principle of protection) and the gravity of the crime committed is an attempt on the fundamental principles of international law and a violation of human rights (the principle of universality). Modern international treaties in the field of combating transnational and international crimes, while establishing the possibility of exercising criminal jurisdiction, do not determine the priority of a principle of extraterritorial jurisdiction and create an alternative.

For example, the same UN Convention against transnational organized crime provides that States parties, without affecting each other's sovereignty and territorial integrity, may establish their jurisdiction over any crime provided for in the Convention when::

(a) The offence is committed against a national of that state party (passive personal principle);

(b) The offence is committed by a national of that state party or by a stateless person who is ordinarily resident in its territory (active personal principle); or

(c) The offence is one of the offences established in accordance with the Convention and is committed outside its territory for the purpose of committing a serious offence in its territory (principle of protection).

The permissibility of the exercise of universal jurisdiction in international treaties is usually not well founded - the Convention's provisions are constructed in such a way as to refer to the domestic law of States parties. Article 16, paragraph 6, of the Convention States: "without prejudice to the rules of General international law, this Convention does not exclude the exercise of any criminal jurisdiction established by A state party in accordance with its domestic law." Thus, it is up to States to decide how broad the scope of extraterritorial jurisdiction can be.

In General, the analysis of international Treaty law and judicial practice shows that the decisive factor influencing the resolution of the conflict of criminal jurisdiction of States is the actual location of the offender. A state may, within the framework of international law, exercise its jurisdiction over a crime committed both within and outside its own territory, regardless of the nationality of the object of jurisdiction, but in this case the jurisdiction will be only prescriptive, substantive. Such jurisdiction in the absence of the accused (in absentia) is limited and negates the achievement of the main objective of the exercise of criminal jurisdiction - the inevitability of punishment.

One of the cornerstones of the competition between the criminal jurisdiction of States is the issue of extradition (extradition) of a person for the purpose of criminal prosecution or enforcement of a sentence that has entered into force. N.A. Safarov rightly notes that "without regard to jurisdictional aspects impossible to implement the results" [3, p. 270]. He identified four main points of contact between the criminal jurisdiction of the state and extradition:

- the extradited person is subject to the jurisdiction of the state in whose territory he or she is located and which decides on extradition;

- close relationship between universal jurisdiction over serious international crimes and extradition;

- the use of their own jurisdiction by the custodial state the suspect as grounds for refusal; and

- clash of jurisdictions of the various States, involving the question of whose criminal jurisdiction takes precedence, and who should issue the face. 
Pre-revolutionary representatives of legal science in Russia and abroad wrote about the close relationship between the criminal jurisdiction of the state and the extradition of criminals in their works. Most of them, however, essentially equated the definition of the spatial scope of criminal law and the extradition of criminals with the main subject of international criminal law. For example, F. F. Martens in his famous work gave the following definition of international criminal law: "International criminal law consists of a set of legal norms that determine the condition of international judicial assistance of States to each other in the exercise of their punitive power in the field of international communication" [5]. Or P.I. Lublinskiy wrote: "we propose to touch on some of the gaps that have emerged in the field of determining the limits of criminal law, or as they call this area, in the field of international criminal law" [6]. V. Ulyanitsky, V. p. Danevsky, V. Spasovich and others, who identified the concept of international criminal law with questions of jurisdiction and mutual legal assistance of States, including extradition of criminals, adhered to the same definition of international criminal law in their works [7].

Recall that in the doctrine of international law, extradition is understood to mean "the process of transfer of a person by a state in accordance with international law to another state for criminal prosecution or the application of criminal punishment" [8]; or " the procedure by which the state under whose criminal jurisdiction the person is prosecuted requests or receives it from the country where it was hiding, for the purpose of subsequent criminal prosecution or enforcement of the sentence»[9]; or "the process of bringing under competent criminal jurisdiction, in accordance with international treaties, national regulations or the principle of reciprocity of the accused or convicted person, for the purpose of criminal prosecution or the execution of punishment" [10]. Without claiming to be new, for the purposes of the study, we will understand extradition as the process of transferring a person from one state under whose jurisdiction he or she is located to another state for the purpose of bringing him or her to criminal responsibility or executing a sentence that has entered into force.

It is generally recognized that the extradition of criminals is one of the oldest institutions of international law, as evidenced by the many sources of the era before our era. According to S. D. Bedi, extradition in any form is an ancient institution, whose origin can be traced back to the origins of civilization, when there was neither a coherent system of international law nor a detailed doctrine about it [11]. That the extradition of criminals found in international legal practice in ancient times, told in the works of V. E. Grabar, E. A. Korovin, D. P. Nikolsky and many other scientists.

At the same time, extradition is also one of the most politicized institutions, the norms of which are closely linked to the right of asylum, and therefore in the process of its development, it has undergone repeated transformation. All these factors have played a decisive role in the ongoing interest in it on the part of representatives of Russian and foreign legal science.

The modern Russian legal studies in the field of extradition of criminals is largely associated with the names of P. N. Biryukov, R. M. Valeeva, Yu. G. Vasiliev, V. M. Volzhenkina, G. V. Ignatenko, I. I. Lukashuk, L. N. Lazutina, A. V. Naumov, N..Safarov, and many others.

Since the General issues of extradition of criminals have been studied in Russian and foreign legal science in sufficient detail, we will not focus on them, but will focus only on the characteristics of extradition as a way to resolve conflicts of criminal jurisdictions of States.

Briefly, this alternative is expressed in the famous Maxim "extradite or judge" - either extradite or judge.

The role that the obligation to extradite or prosecute has played in international cooperation in combating impunity has been recognized since the time of Hugo Grotius, who postulated the principle of aut dedere aut punire (either extradite or punish) in this way: "the State in which the person who is found guilty of a crime must either itself, at the request of another state, punish the offender on merit or submit it to the consideration of the state concerned" [12]. The wording of the obligation in the modern period is as follows: "Each Contracting State shall take such measures as may be necessary to establish its jurisdiction over the offences in cases where the alleged offender is present in its territory and it does not extradite him to any of the States parties", declared its jurisdiction.

Rule aut dedere aut judicare was actively prescribed in international treaties in the period from the second half of the twentieth century. This is largely due to the consequences of the Second world war and the need to fight fundamentally against impunity for crimes under international law.

Since the beginning of the twenty-first century, increased attention to the legal content of the principle of aut dedere aut judicare and its practical implementation is largely due to the intensification of the activities of international terrorist associations, the increase in the number of international and internal armed conflicts, as a result of which massively and grossly violated human rights, and, as a consequence, the revision of the entire international legal concept of the right of asylum. There was a General understanding of the exclusion of terrorist crimes and crimes against the peace and security of mankind from the category of political crimes and the need to strengthen international legal guarantees to prevent impunity for the acts committed.

In 2004, at the fifty-sixth session, the UN international law Commission decided to include in its programme of work the topic "Obligation to extradite or prosecute (aut dedere aut judicare)". During the three-year period, the ILC received and considered three reports of the special Rapporteur on the subject. The working group established by the Commission in 2008 identified a number of issues to be considered in detail in the context of the development of the principle aut dedere aut judicare, which were called The General framework 2009. Among them:

- legal basis of the obligation to extradite or prosecute (whether and to what extent the obligation to extradite or prosecute is based on customary international law); 
- the material scope of the obligation to extradite or prosecute (determination of the categories of crimes covered by the obligation aut dedere aut judicare, and whether the recognition of a criminal act as an international crime is sufficient for the existence of the obligation);

- the content of the obligation to extradite or prosecute (whether the order of the two elements matters and whether one element takes precedence over the other);

- relationship between the obligation to extradite or prosecute and other principles (relationship to the principle of universal jurisdiction, non-extradition of nationals, principles of international criminal law nullum crimen sine lege, nulla poena sine lege, non bis in idem;

- conditions for giving effect to the obligation to extradite or prosecute (presence of the alleged offender in the territory of the state; existence of state jurisdiction over the offence in question; existence of a request for extradition and others); - practical implementation of the obligation to extradite or prosecute;

- the relationship between the obligation to extradite or prosecute and the surrender of the alleged offender to a competent international criminal Tribunal ("third alternative")

The Commission also reviewed multilateral conventions containing provisions combining extradition and prosecution as an alternative to punishment (2010) in order to resolve these issues.

An important judicial precedent directly relevant to the issue under consideration and directly related to the principle of aut dedere aut judicare was the decision of the United Nations international court of justice in 2012 in the case concerning the former President of the Republic of Chad, hissène habré - issues relating to the obligation to prosecute or extradite (Belgium V. Senegal) - the materials of which also served as the basis for the elaboration of the normative elements of the principle.

7 Aug 2014 the ILC decided to conclude its consideration of the topic "Obligation to extradite or prosecute (aut dedere aut judicare)". The originally planned submission of the outcome of the work in the form of draft articles had not been successful, but the Commission had recommended that States should use its results as a guide to action.

\section{Summary}

If we summarize the main results of the work of the Commission over the subject, it is possible to allocate four basic normative element, reflected in the presented General framework of 2009, and which form the main legal content of the obligation aut dedere aut judicare.

The first element relates to the source of the obligation: how confident it is to speak of the exclusively conventional basis of the alternative, and whether this rule can be considered opinio juris, at least for some of the most serious crimes. In this part, it should be noted that this issue was considered by the Commission during the drafting of the Code of crimes against the peace and security of mankind.

It is considered that the principle of aut dedere aut judicare is derived from the provisions of the multilateral universal and regional conventions (about sixty), the analysis of which was undertaken by the Secretariat in 2010, and submitted to the Commission as the review of the multilateral conventions which may be useful for the Commission in its work on the topic "the Obligation to extradite or prosecute (aut dedere aut judicare)" (a Review of the Secretariat 2010). In the process of identifying similarities and differences between the rules under consideration in terms of the formulation of the obligation, its evolution was traced, and all conventional sources were divided into four categories: a) the Convention for the suppression of counterfeiting of 1929 and other conventions of the same model; b) regional extradition conventions; C) the Geneva conventions of 1949 and Additional Protocol I of 1977; d) the Hague Convention for the suppression of unlawful seizure of aircraft of 1970 and other conventions of the same model.

The latter, the "Hague formula", served as a model for almost all universal conventions concluded in the modern period. The mechanism of disclosure of the "Hague formula" in practice can be traced to the judicial process initiated by Belgium against Senegal in respect of the non-extradition of Hissène Habré. The Court's ruling examines in detail the provisions of the 1984 UN Convention against torture and other cruel, inhuman or degrading treatment or punishment relating to the establishment of jurisdiction, the obligation to participate in preliminary investigations and the obligation to extradite or prosecute. Since the relevant provisions of the Convention are formulated according to the "Hague formula", the Court's decision greatly contributes to clarifying the legal regime of extradition or prosecution for other conventions of the same model. As judge Donoghue noted, "the dispositive clauses of today's opinion are binding only on the Parties. However, the Court's interpretation of a multilateral Treaty (or customary international law) may have implications for other States. The far-reaching implications of the legal issues raised by this case are indicated by the large number of questions raised by members of the Court during oral hearings..."

At the same time, the comments submitted on behalf of our country state that "the Russian Federation a priori does not exclude the existence of a rule of customary international law obliging States to extradite or prosecute persons in respect of certain categories of crimes. We believe, however, that the existence of such a rule and its scope can only be ascertained if the relevant practice of States is identified in the absence of Treaty obligations, as well as evidence that States do so precisely because they consider themselves bound by a rule of law". Accordingly, the application in the Russian Federation is linked to the obligation of aut dedere aut judicare to the extent that Russia exercises its criminal jurisdiction on a universal principle on the basis of an international Treaty containing this principle.

In 2011, the special Rapporteur proposed a draft article on the subject, "international custom as a source of obligation aut dedere aut judicare", for consideration by the Commission»: 
1. Each state is under an obligation either to extradite or prosecute the alleged offender if such an obligation arises from a customary rule of international law.

2. Such an obligation may arise, inter alia, from the customary rules of international law relating to serious violations of international humanitarian law, genocide, crimes against humanity and war crimes.

3. The obligation to extradite or prosecute derives from a peremptory norm of General international law adopted and recognized by the international community of States (jus cogens) in the form of an international Treaty or international custom by which any person who commits the acts referred to in paragraph 2 is recognized as a criminal".

However, the draft article had not received the support of either the members of the ILC or the Sixth Committee of the United Nations, as it had decided that the alternative of "extradite or prosecute" did not automatically follow the normal rule of the prosecution of serious crimes under international law.

The question of the attribution of the obligation aut dedere aut judicare to customary international law was raised in part in the proceedings of Belgium V. Senegal in the case of H. Habré. The court held that it was not competent to deal with the matter because it was a violation of a particular international Treaty and not of customary law. At the same time, in his separate opinion, judge Abraham stated that there was sufficient evidence, based on state practice and opinio juris, of a customary obligation for States to prosecute in their domestic courts individuals suspected of war crimes or crimes against humanity based on universal jurisdiction even if the suspect is in the territory of the forum state.

As a result, the Commission also decided to bypass this issue. Without giving an unambiguously positive answer, the final report on the topic of the ILC contains a vague phrase that "the above should not be interpreted as concluding that the obligation to extradite or prosecute has not yet become and is not becoming a rule of customary international law, whether General or regional".

Second. Of course, of paramount importance is determining the primacy of one part over the other alternatives: how wide the margin of appreciation available to the state, taking the decision to grant or refuse it. In other words, what the obligation States: the primacy of "give" or the advantage of "judge".

In this part, the analysis of Treaty international law showed that the degree of specificity of the formulation of the obligation aut dedere aut judicare is very variable and depends largely on the geographical, institutional and thematic affiliation of the Treaty, as well as on other factors, such as: the development of human rights and the formation of the system of international criminal justice. In its commentary on the topic submitted to the Commission in 2009, Belgium identified two types of treaties: (a) those containing the aut dedere aut judicare clause and the obligation to prosecute by refusing a request for the extradition of an alleged offender; and b) treaties containing the judicare vel dedere clause and obliging States to exercise universal jurisdiction over the perpetrators of serious crimes provided for in the conventions, which do not make this obligation conditional on the existence of a refusal to grant a prior request for extradition. In the final report of the ILC on the topic all treaties were also divided into two large groups: "(a) those under which the obligation to prosecute arises only as a result of the refusal to extradite the alleged offender upon request, and (b) those that impose an obligation to prosecute ipso facto when the alleged offender is found in the territory of a state that can be exempted from that obligation if the person is extradited".

In its final report on the topic, the Commission decided that the primacy of the obligation to "extradite" over "prosecute" was entirely dependent on the context and the applicable law in each specific situation. States, in drafting treaties, can decide which formula for the obligation to extradite or prosecute best suits their purpose. And since there is no uniformity in Treaty practice in the formulation of an obligation, "...the Commission's participation in the process of negotiating the various Treaty clauses relating to the obligation to extradite or prosecute would be futile".

The third element concerns the establishment of the scope or range of crimes covered by the obligation.

As already noted, some sixty universal and regional conventions in international criminal law contain a provision containing an alternative to aut dedere aut judicare, and accordingly States parties undertake to criminalize the act in question and to establish their jurisdiction.

Most of the crimes of a transnational nature do not raise questions as to the criminal prosecution of the suspect or the prosecution of the suspect. The situation is more complicated in the case of violations of the fundamental principles of international law, norms of jus cogens, global foundations of the world legal order.

It should be noted that, in the process of developing a conventional framework for the alternative of "extradite or prosecute", the Commission has identified significant gaps in its consolidation with respect to most crimes against humanity, war crimes other than serious violations and war crimes committed in non-international armed conflicts. Even with regard to the crime of genocide, the members of the Commission considered it desirable to strengthen the regime of international cooperation beyond the basic regime of the Convention, since it "merely obliges the Contracting parties to establish and exercise territorial criminal jurisdiction, as well as to cooperate with the international criminal court in certain circumstances".

With regard to the relevant provisions of the Geneva Conventions of 1949, they contain the same rule that each party undertakes to search for persons accused of committing or ordering a serious violation and, regardless of their nationality, to bring them to justice. Extradition is an option here, provided that the state exercising jurisdiction has evidence to support the prosecution. However, on the basis of the judgment of the Court in the case of Questions relating to the obligation to prosecute or extradite (Belgium V. Senegal), according to which the prohibition of torture is a peremptory norm of jus cogens, the formula of the obligation to "extradite or prosecute", as set out in the Convention against torture could serve as a model for application in the context of the prosecution or the issuance by the Commission of other serious crimes under international law such as genocide, war crimes and crimes against humanity. 
Finally, the fourth element describes the obligation in terms of the possibility of transferring a person to the jurisdiction of an international criminal court (the third alternative), as well as its relationship with universal jurisdiction.

The adoption of the Statute of the International criminal court in 1998 and the gradual development of the international criminal justice system, including the establishment of the international criminal tribunals ad hoc and the establishment of a network of internationalized (hybrid) courts, allowed for a rethinking of this provision in the light of the opportunities presented. As a result, already in 2006, the international Convention for the protection of all persons from enforced disappearance, as a "third alternative" to extradition or prosecution, transfers the suspect to the relevant international criminal court: "If the alleged perpetrator of the crime of enforced disappearance is found in the territory under the jurisdiction of the state party, and if that state does not extradite the person in question or transfer him to another state in accordance with its international obligations or to the international criminal court, whose competence it recognizes, it shall refer the case to its competent authorities for prosecution" (art.11, para. 1). It is thought that in the near future, international agreements containing three options for the state party to choose its own conduct with respect to extradite, transfer to an international criminal Tribunal or prosecute will be concluded more. At the same time, of course, the participants themselves should be interested in a clear formulation of such an alternative in order not to be involved in the international judicial process.

\section{Conclusion}

Thus, the existence in international law of various legal grounds for the exercise of criminal jurisdiction necessarily implies competition between the criminal jurisdiction of States. The decisive factor in resolving conflicts of state criminal jurisdiction is always the actual location of the offender. A state may, within the framework of international law, exercise its jurisdiction over a crime committed both within and outside its own territory, regardless of the nationality of the object of jurisdiction, but in this case the jurisdiction will be prescriptive, substantive. Such jurisdiction in the absence of the accused (in absentia) is limited and negates the achievement of the main objective of the exercise of criminal jurisdiction - the inevitability of punishment. At the same time, the advantage of the territory does not exclude the existence of a conflict of criminal jurisdictions of States, inevitably entails the need to address many procedural issues, including extradition.

\section{Acknowledgements}

The work is performed according to the Russian Government Program of Competitive Growth of Kazan Federal University.

\section{References}

[1] Dixon M. Textbook on International Law. 7th ed. Oxford University Press, 2013. P. 159.

[2] Chernichenko, O. S. International legal aspects of state jurisdiction: author., Phd thesis, Sciences; Diplomatic Academy of the Ministry of foreign Affairs of the Russian Federation. M., 2003. 31 p., p. 12.

[3] Safarov N. Ah. Extradition in international criminal law: problems of theory and practice. Extradition in International Criminal Law: Problems or Theory and Practice. M.: Volters Kluver, 2005. P. 69.

[4] Khusnutdinov R. R. territorial and extraterritorial effect of the criminal law: autoref. Diss. ... kand. Jus. of Sciences; Kazan state University, 2007. p. 17.

[5] Martens F. F. Modern international law of civilized Nations. SPb. In 1905. Vol.2. p. 388.martens

[6] Lublinskiy P. I. Questions of international criminal law in connection with this war. Pg. In : proceedings of Mead, 1917. kN. 1, 2. P. 216.

[7] Ulyanitsky V. International law. Tomsk, 1911. P. 319; Dinevski V. P. Handbook for the study of the history and system of international law. Kharkov, 1892. Issue. 2. P. 33; Spasovich V. Textbook of criminal law. SPb., 1863. Vol.1. P. 74.

[8] Galenskaaa L. N. The international fight against crime. P. 122; Valeev R. M. Extradition of criminals in modern international law: some questions of theory and practice. Kazan, 1976. P. 28-29.

[9] VolzhenkinaV. M. Results in the Russian criminal process. M., 2002. P. 183; Safarov N. M. Extradition in international criminal law: problems of theory and practice. p. 16.

[10] Lazutin L. A., Rabtsevich, O. I. Legal assistance and legal relations between the States in penal matters: issues of theory and practice. Ekaterinburg, 2010. P. 165.

[11] Bedi S.D. Extradition in international law and practice. Rotterdam, 1966. P. 16.

[12] Hugo Grotius. De Jure Belli ac Pacis, Book II, chapter XXI, section IV. English translation by Francis W. Kelsey Oxford/London: Clarendon Press/Humphrey Milford, 1925. P. 527. 